\begin{tabular}{ll}
\hline 臨 & 床 \\
\hline
\end{tabular}

\title{
めまいで発症した若年成人の延髄梗塞例
}

\author{
足達亜貴子・瀬尾徹*・安野 博樹 \\ 藤木 宏也・寺田 友紀*・阪上 雅史*
}

\section{A Case Report of Medullary Infarction with Vertigo in a Young Adult}

\author{
Akiko Adachi, Hiroki Yasuno and Hiroya Fujiki \\ (Takarazuka City Hospital) \\ Toru Seo, Tomonori Terada and Masafumi Sakagami \\ (Hyogo College of Medicine)
}

It is generally known that cerebral infarction commonly occurs in elderly people. Rarely, cerebral infarction may occur in young adults due to complications such as collagen disease, heart disease, and dissecting aneurysm. We recently encountered a 32 -year-old man who had occasionally complained of occipital pain after drinking alcohol since April 1999. As he also experienced sudden onset of vertigo with occipital pain, he went to the Department of Otolaryngology, Takarazuka City Hospital on April 14, 1999. Left-ward horizontal-rotatory spontaneous nystagmus was presented as shown in vestibular dysfunction. There were not any cerebellar signs, but left trigeminal hypesthesia suggested a central nervous system disorder. Moreoever, we found disturbances of touch, temperature, and pain sensations on the right upper and lower extremities.

MRI showed an infarction in the left lateral medulla oblongata. Vertebral angiography showed an aneurysm in the distal and proximal segments of the left posterior inferior cerebellar artery. These findings indicated that medullary infarction was caused by dissecting aneurysm of the vertebral artery.

In the present case, it was suggested that the intima of the vertebral artery rapidly deteriorated due to the dehydration resulting from excessive alcohol intake, and that neurological examination should be performed even in juvenile vertiginous cases.

Key words : medullar infarction, vertigo, young adult, dissecting aneurysm

はじめに

一般に脳梗塞は動脈硬化や高血圧を基礎疾患に持つ高 齢者に多く, 若年者に発症する場合は全脳梗塞のうち約 $3.6 \sim 5.1 \%$ と比較的少ない1)2. しかし心疾患, 膠原病, 凝固線溶系異常などの基礎疾患が存在する場合は, 若年
者にも発症することがあり, 解離性動脈瘤もその原因の 一つとして知られている3 ${ }^{3}$. 椎骨動脈系の解離性動脈瘤 は, めまい, 後頭部痛が前駆症状としてみられる場合が 多く, めまいを扱う耳鼻咽喉科医もその存在は知ってお く必要がある4).今回われわれは, 若年成人で回転性め 
まいで発症した椎骨動脈解離性動脈瘤に起因すると思わ れる延䯑有梗塞の 1 例を経験したので報告する.

\section{症例}

症例 : 32 歳, 男性.
主訴：回転性めまい, 後頭部痛.

既往歴: 6 年前, 肺結核にて内服加療を受けたことが ある(ストレプトマイシンは使用されていない)。高血圧 なし。

家族歷：特記すべきことなし．

\section{$I^{\prime}$ '}
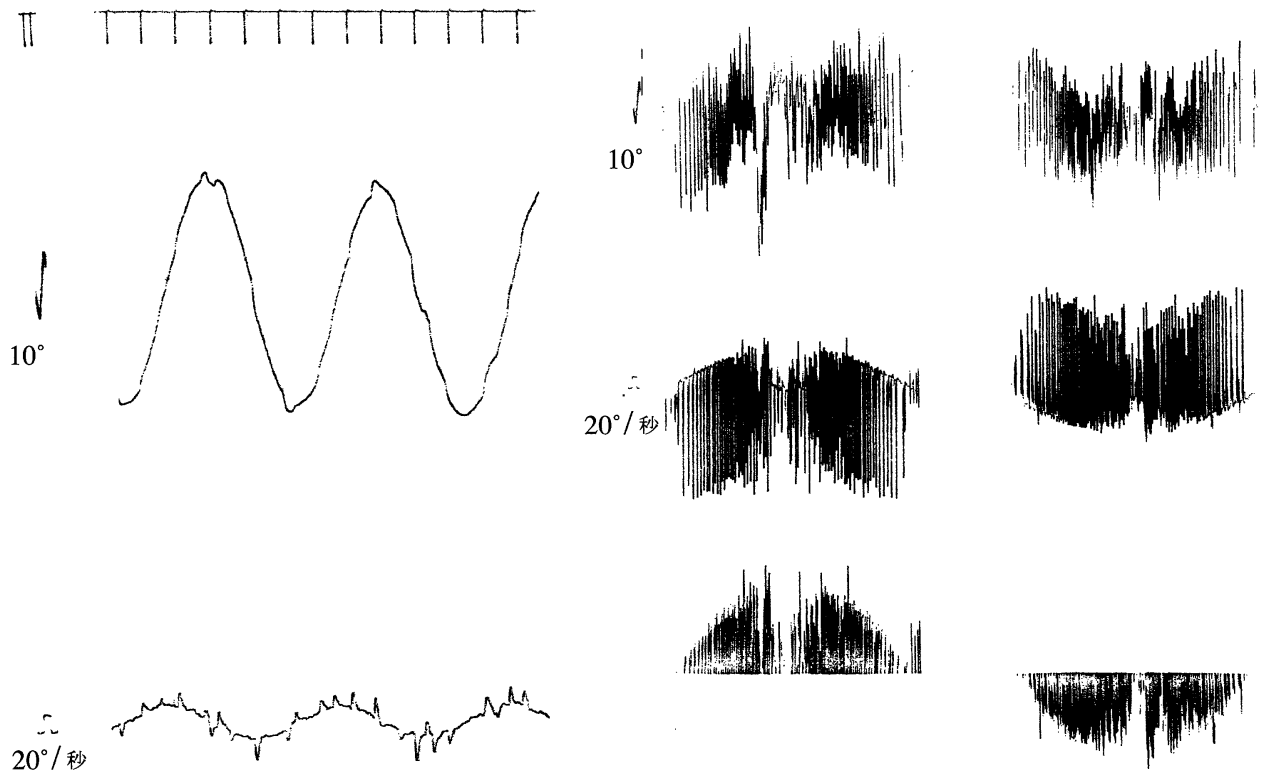

a. 追跡眼球運動検查
やや階段状を呈している.

b. 視運動性眼振検查 左右差なく, 解発抑制はみられない.

ii

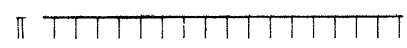

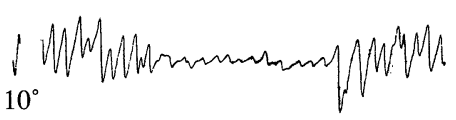

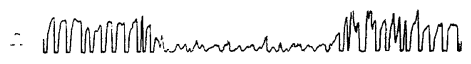
$20^{\circ} /$ 秒

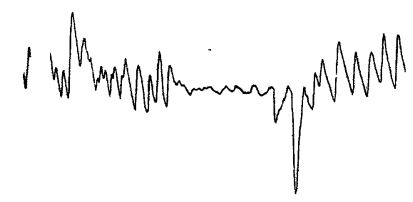<smiles>CC=C(C)CC</smiles>

固視

\section{固視}

R-VS

L-VS

c. Visual suppression test（右側：71\%, 左側 : $71 \%$ ) 両側とも固視により解発抑制されている. 
現病歷：本来ほとんど飲酒しないが, 平成 12 年 4 月上 旬頃より飲酒の機会が多くなり, 飲酒後左後頭部痛をき たすことがあった. 同年 4 月 14 日，起床後急に後頭部痛 を伴って回転性のめまいが出現し, 歩行困難となったた め同日当科を受診した．蝸牛症状はなかった。

現症 : 耳鼻咽喉頭に異常なく, 純音聴力検査む正常で あった. 注視眼振検查で左向きの水平回旋混合性眼振を 全注視方向で認め, フレンツェル眼鏡下にも左向き水平 回旋混合性自発眼振を認めた。 小脳症状は認めなかった が，左三叉神経領域の知覚低下を認めたため中枢性のめ まいを疑い, 精查のため入院した。

入院中の神経耳科学的検查では, $20^{\circ} \mathrm{C}$ 刺激冷水力口 リックテストで右が $30 \%$ 秒, 左が $40 \%$ 秒と正常であっ た. 追跡眼球運動検査（図 $1 \mathrm{a}$ ）ではやや階段状を呈して いたが，視運動性眼振検查では異常なかった（図 $1 \mathrm{~b}$ ）。 Visual suppression test も正常であった (図1c). ABR は左 右差なく I-V 波間隔の延長は認めなかった（図 2)。一般 神経学的には右上下肢の温痛覚, 触覚の低下を認めた. 血液検查では CK $563 \mathrm{U} / \mathrm{L}$ と高値, TC $226 \mathrm{mg} / \mathrm{dl}$, TG $214 \mathrm{mg} / \mathrm{dl}$ とやや高值である以外, WBC $76.1 \times 10^{2} / \mu \mathrm{l}$, $\mathrm{RBC} 487 \times 10^{4} / \mu \mathrm{l}, \mathrm{PLt} 18.4 \times 10^{4} / \mu \mathrm{l}$ で凝固系検查も異常 を認めず，他も正常範囲内であった。

MRI 検查：T2 強調画像で左延髄外側に楔形の高信号域 を認め，いわゆる延骾外側症候群に一致する梗塞像と考 えた（図 $3 \mathrm{a}$ )。Gd 造影 $\mathrm{T} 1$ 強調画像では左椎骨動脈の狭 窄像（図 $3 \mathrm{~b}$ )，および血管内腔に解離壁を疑う線状の低 信号域, いわゆる intimal flap を認め (図 $3 \mathrm{c}$ ), 解離性動

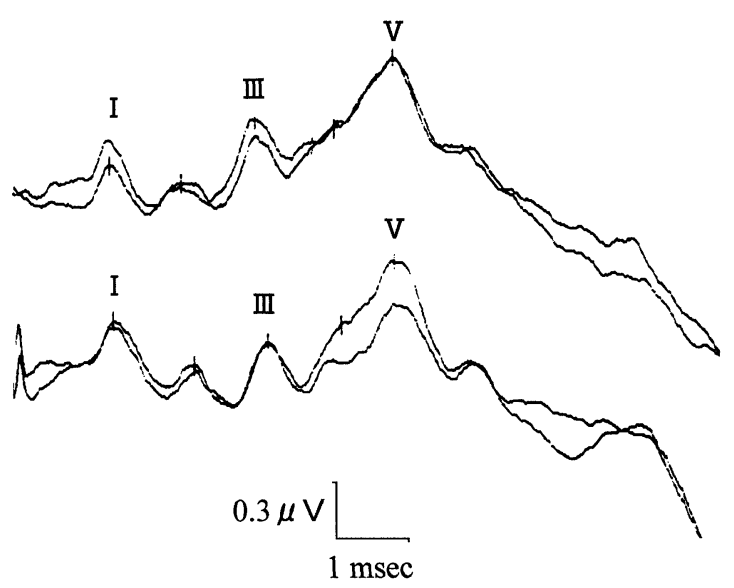

図 $2 \mathrm{ABR}$ (上段 : 右刺激, 下段 : 左刺激) 左右差なく I-V 波間隔の延長を認めない.
脈瘤を強く疑った。

脳血管造影所見: 左椎骨動脈の血管造影を示す (図 4). 左後下小脳動脈が分岐する前後で左椎骨動脈の狭窄像を 認めた。 以上より, 左椎骨動脈が解離性動脈瘤によって 血管内腔の狭窄を生じ, 後下小脳動脈の循環障害を引き 起こした結果, 延髄梗塞を発症したと考えられた。

経過 : 入院後, 抗めまい剤や循環改善剤の点滴を施行 し, めまいの性状は回転性から浮動性へと変化した. 発 症から約 4 日目に歩行可能, 約 2 週間でめまいがほぼ消 失したため 4 月 28 日退院した。

入院時に認めた左向き水平回旋混合性自発眼振は発症 から約 1 力後には消失した. また左後頭部痛は徐々に 改善したが, 左顔面のしびれは発症後約 4 力月で消失し た. 右上下肢の温痛覚, 触覚低下については発症後4カ 月まで認めたが，その後徐々に軽快し発症 1 年 9 力月目 の現在, 感覚はほぼ回復している. 1 年 9 力月目の MRI では T2 強調画像にて延髄外側に高信号域を認め, 発症 時と変化はなかった. しかし, 発症時に MRI で認めた血 管の狭窄像は消失し, 血管腔は保たれていた。再発の可 能性も否定できないため, 外来にて経過観察を行ってい る.

\section{考 察}

若年性脳梗塞は全脳梗塞の約 $3.6 \sim 5.1 \%$ を占めると いわれている ${ }^{122)}$. 高齢者の脳梗塞の多くは動脈硬化に基 づくことが多いが5)，若年発症の場合はその原因は多岐 にわたる，心原性脳塞栓症が最も多く，血管炎をきたす 膠原病や血球異常, 凝固, 線溶系異常, ネフローゼ症候 群や妊娠 5$)$ ，下痢などの脱水 ${ }^{6)}$ 等が知られている．その なかで最近注目されているものに解離性動脈瘤があり, 若年性脳梗塞の約 4\%を占めるといわれている7). また, 比較的若い年齢層の脳梗塞および後頭蓋窩のくも膜下出 血をみたときには，解離性脳動脈瘤を疑うべきとする報 告もある81

解離性動脈瘤は血管内膜の部分的破錠により内膜と中 膜の間に血液が漏出することにより形成され，その結果， 血管内腔が狭窄ないし閉塞し脳梗塞をきたすといわれて いる7) 9). 解離性脳動脈瘤の発生部位は椎骨動脈が最も 多く $80 \sim 90 \%$ を占める ${ }^{8}$. そのなかでも特に椎骨動脈が 硬膜を貫通する部位（第 1 頸椎から両側椎骨動脈の合流 部まで） 2）や，椎骨動脈が強固に固定されておらず可動 性が大きいため鈍的外傷を受けやすい第 2 頸椎横突起か 


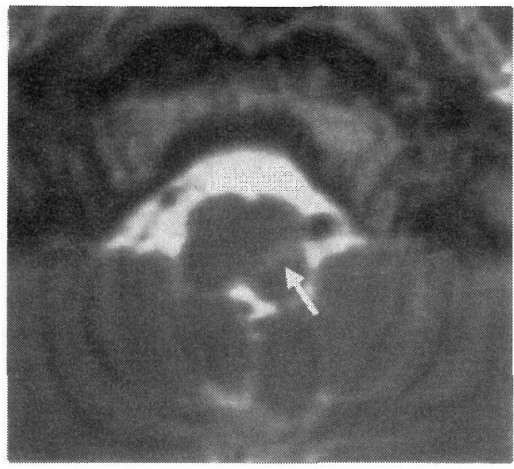

a

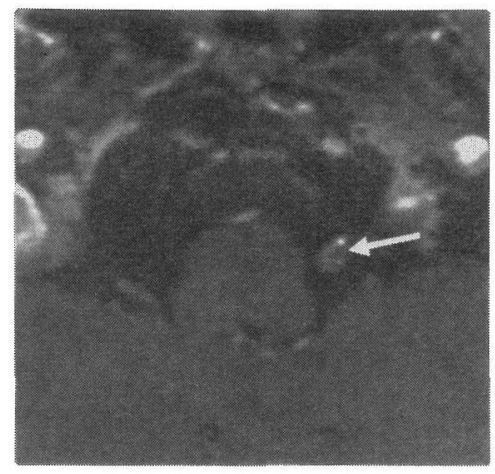

b

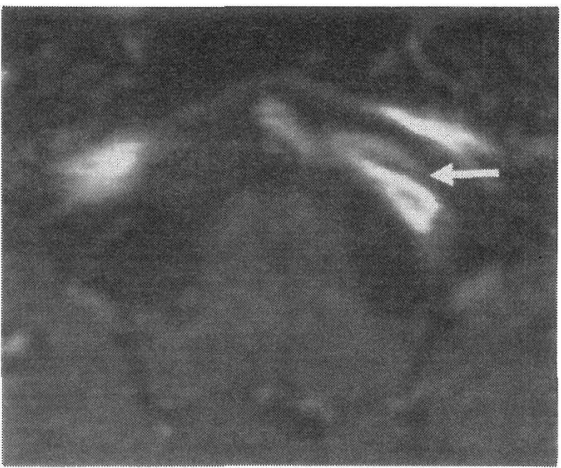

c

図 3 MRI

$\mathrm{a} ： \mathrm{~T} 2$ 強調画像. 延髄外側に楔状の高信号域を認める.

b : Gd 造影 T1 強調画像. 左椎骨動脈内腔に血栓および隔壁を疑う低信号域を認め, 血管内腔が狭窄している.

$\mathrm{c} ： \mathrm{Gd}$ 造影 T1 強調画像. 左椎骨動脈内腔に解離壁と考えられる intimal flap を認める.

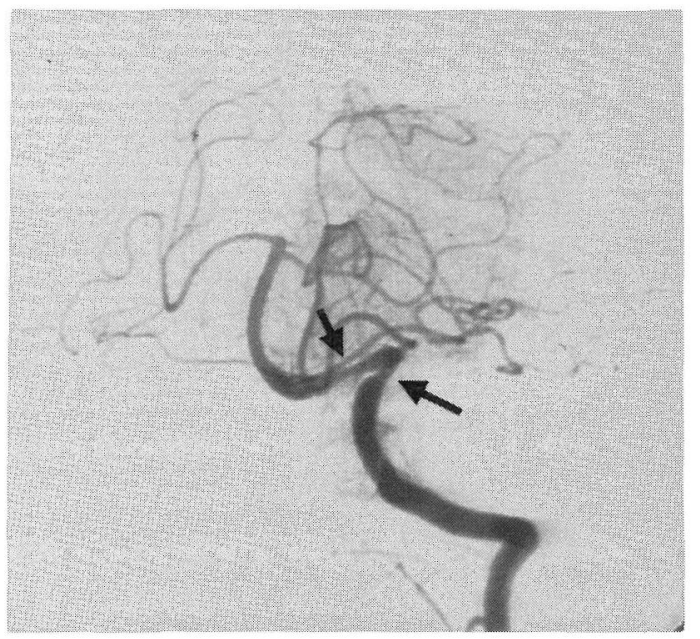

a

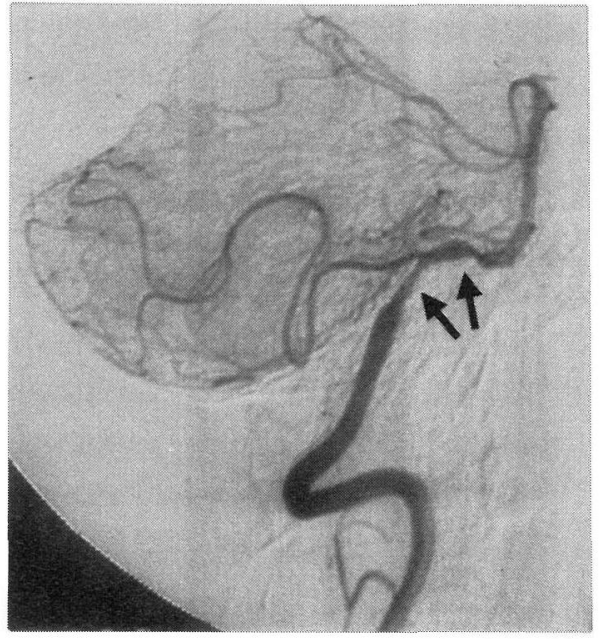

b

図 4 脳血管造影 (左椎骨動脈. a : 正面像 $\mathrm{b}$ : 側面像)

左後下小脳動脈が分岐する前後で左椎骨動脈が狭窄しているのを認める (矢印).

ら第 1 頸椎横突起までに特に多く認められるとの報告が ある10)。わが国では，若年から中年に発症した延髄外側 症候群の原因として頭蓋内椎骨動脈解離が多いことが注 目されている99. また，椎骨動脈解離性動脈瘤の特徴は 前駆症状として後頭部痛，めまいを呈することが多く， 比較的若年の男性に多いとされている2).

一般に, 解離性動脈溜の治療は保存的に行われること が多(7) 9)11). 動脈解離の際, 壁在血腫の圧迫で血管内 皮が傷害されたり，血管内腔を閉塞して血行が停滞する
ことにより，血管内腔では血检が形成されやすい状態と なっていると考光られている，そのため，血栓形成を予 防する目的で抗血小板療法や抗凝固療法が有効と考光ら れている9）方効果は確立されておらず，逆にくも膜下出 血や解離を進展させる危険むあるため, 盲目的な投与は 控えるべきともいわれている ${ }^{81}$ 。实た，保存的治療でも 症状を繰り返すものや動脈瘤様の増大傾向がみられる ものはクリッピングなどの外科的治療が考慮されてい る7)8111). 本症例では症状の再発は認めず, 経過後の MRI 
で梗塞像の変化は認めないものの, 動脈瘤の所見は改善 していたのでこのまま経過観察でよいと思われた。

本症例の発症機序について考えてみると，もともと血 管壁に脆弱な部位が存在していたのが一時的な多量の飲 酒により血管内の脱水，血液の粘度が充進し，それによ り血管内腔の解離が一気に進行し, 血管内腔の狭窄が生 じ脳梗塞をきたしたと考えられた。特にめまいが発症す る前に繰り返し起こっていた後頭部痛は, 血管の解離が 進行していたといら徴候とも考光られる.今回の症例は, 1）若年者, 2) 椎骨動脈解離性動脈瘤の好発部位であっ た，3）前駆症状は後頭部痛とめまい, などの特徴と合致 する点が多く, 典型例と考えられる.このため椎骨動脈 解離性動脈瘤による脳梗塞はめまいを取り扱う耳鼻咽喉 科医としては念頭に置かねばならない，本症例は臨床所 見的には延髄外側症候群（Wallenberg 症候群）に類似し, 中枢性めまいを疑った根拠は三叉神経の知覚低下であっ た. 若年者のめまいにおいても脳神経所見を観察するこ とが非常に重要と思われる12).

\section{まとめ}

若年成人で回転性めまいで発症した椎骨動脈解離性動 脈瘤に起因すると思われる延髄梗塞の 1 例を報告した. 本症例は左椎骨動脈の血管壁にもともと脆弱な部分が存 在し, 一時的な多量の飲酒による脱水で急激に解離が進 行し, 後下小脳動脈の循環障害から延髄梗塞を起こした ものと考えた．若年者でも脳血管異常や解離性動脈瘤な どの基礎疾患を有する場合, 脳梗塞をきたしうるため, 若年者のめまいでも脳神経所見を観察することが非常に 重要と思われた.

本論文の要旨は第 60 回日本めまい平衡医学会 (東京, 2001 年）にて口演した.

\section{参考文献}

1）山口武典, 橋本洋一郎 : 若年者の脳卒中. 臨床と研究 62 : $3517 \sim 3522,1985$.

2）丸山芳一: 若年性脳梗塞一危険因子を有さない 11 例の凝血. 学的検討一. 脳卒中 $12: 1 \sim 6,1990$.

3）伊澤直樹, 小鷹昌明, 結城伸泰, 他 : 後下小脳動脈解離に より発症した若年性小脳梗塞. 神経内科 $53: 170 \sim 172$, 2000.

4）新井基洋, 樋口彰宏, 伊藤能成, 他 : めまいを初発症状と した椎骨動脈解離性動脈瘤の 1 症例. 耳喉頭頸 $73: 496$ 501，2001.

5）松崎 茂, 松田 実: 神経症候群 I, 若年性多発性脳梗塞. 日本臨牀 別冊 領域別症候群 $26: 120 \sim 123,1998$.

6）奥村孝子, 角谷昌昭, 中山明峰, 他：若年性脳梗塞に併発 した前下小脳動脈症候群. 耳鼻臨床 補 $104: 81 \sim 84,2000$.

7) 太田富雄：解離性動脈瘤. 脳神経外科学（太田富雄, 杉谷 雅生編). $829 \sim 834$ 頁, 金芳社, 京都, 2000 .

8) 山浦 晶, 小林英一: 解離性脳動脈瘤. 脳血管障害の臨床. 日本医師会雑誌 $125: 226 \sim 231,2001$.

9）西村裕之, 浅田直子, 立花久大, 他 : 椎骨動脈解離により 生じた Wallenberg 症候群. 神経内科 $53: 409 \sim 411,2000$.

10）稲福徹也, 高木 誠：動脈解離による脳梗塞. 脳血管障害 の成因 (吉田亮一, 内山真一郎, 江藤文夫編). $175 \sim 183$ 頁, 現代医療社, 東京, 1998 .

11）蓮江正道, 福田忠治, 中島 智, 他: 解離性動脈瘤の治療. 脳卒中の外科 $21: 361 \sim 367,1993$.

12）瀬尾 徹, 富永了, 行政暁子, 他：MRI で橋部に T2 高 信号を認めためまいの検討. 耳鼻臨床 95:225〜 231, 2002.

原稿受付：平成14年 3 月 5 日 原稿採択：平成14年 5 月 8 日 別刷請求先 : 足達亜貴子 干663-8501 西宮市武庫川町1-1 兵庫医科大学耳鼻咽喉科学教室 